Table 1 Companies receiving NHGRI awards

\begin{tabular}{|c|c|c|c|}
\hline Company (location) & Investigator(s) & $\begin{array}{l}\text { Award }{ }^{a} \\
\text { (duration) }\end{array}$ & Description \\
\hline $\begin{array}{l}\text { Electronic Bio Sciences } \\
\text { (San Diego) }\end{array}$ & Geoffrey Barrall & $\begin{array}{l}\$ 4,322,000 \\
(4 \text { years) }\end{array}$ & $\begin{array}{l}99.99 \% \text { accurate, direct DNA sequencing by } \\
\text { means of the protein nanopore method }\end{array}$ \\
\hline Helicos BioSciences & John Thompson & $\begin{array}{l}\$ 2,900,000 \\
(2 \text { years) }\end{array}$ & $\begin{array}{l}\text { Providing the } \$ 1,000 \text { genome through } \\
\text { improved single-molecule sequencing }\end{array}$ \\
\hline $\begin{array}{l}\text { IBM (Yorktown Heights, } \\
\text { New York) }\end{array}$ & $\begin{array}{l}\text { Gustavo Alejandro } \\
\text { Stolovitzky }\end{array}$ & $\begin{array}{l}\$ 2,547,000 \\
(3 \text { years })\end{array}$ & $\begin{array}{l}\text { Nanopore-based electrical device for DNA } \\
\text { sequencing }\end{array}$ \\
\hline $\begin{array}{l}\text { Ion Torrent Systems } \\
\text { (Guilford, Connecticut) }\end{array}$ & $\begin{array}{l}\text { John H. Leamon and } \\
\text { Jonathan Rothberg }\end{array}$ & $\begin{array}{l}\$ 2,255,000 \\
(2 \text { years) }\end{array}$ & $\begin{array}{l}\text { Development of a semiconductor-based plat- } \\
\text { form for genomic sequencing }\end{array}$ \\
\hline $\begin{array}{l}\text { GE Global Research } \\
\text { (Niskayuna, New York) }\end{array}$ & John Nelson & $\begin{array}{l}\$ 1,344,000 \\
(2 \text { years })\end{array}$ & Closed complex single-molecule sequencing \\
\hline Pacific Biosciences & Stephen Turner & $\begin{array}{l}\$ 1,900,000 \\
(2 \text { years })\end{array}$ & $\begin{array}{l}\text { Direct, single base-pair, real-time DNA meth- } \\
\text { ylation sequencing }\end{array}$ \\
\hline $\begin{array}{l}\text { Lightspeed Genomics } \\
\text { (Santa Clara, California) }\end{array}$ & Jekwan (Josh) Ryu & $\begin{array}{l}\$ 243,000 \\
\text { (6 months) }\end{array}$ & $\begin{array}{l}\text { Deep-submicron optical detection for high- } \\
\text { density, high-throughput DNA sequencing }\end{array}$ \\
\hline
\end{tabular}

aFunding either under auspices of ARRA (\$113 million); \$19 million provided from other funds. Source: http://www.genome. gov/27534236

who described how federal stimulus funds are affecting their business during a third-quarter earnings call. "To capture that revenue, we are bringing in a significant number of additional sales resources in the US next year [to] focus on larger academic accounts that are the recipients of these funds," Brust says.

In terms of the purchasing being done by academic or comparable sequencing centers, 454 Life Sciences, a division of Roche, in Branford, Connecticut; Illumina in San Diego; and Applied Biosystems, a division of Life Technologies, are currently the three biggest players, with Helicos BioSciences and Pacific Biosciences, likely filling the next tier, according to Schloss, who is care- ful not to endorse any particular commercial approach. “The Institute's [NHGRI] goal is to see [that] these technologies are developed and useful, and we are agnostic as to whether it's by academics or companies," Schloss says. If a promising technology "is being commercialized, we don't want to stand in the way."

"I am not sure the stimulus money will have any differential effect on the companies, but it certainly will add a few extra orders into their systems," says Jonathan Eisen of the Genome Center at the University of California, Davis. "That would not have happened otherwise. But as for which ones get the money, that will still come down to which ones are better."
Another important point is that the stimulus package is "democratizing sequencing" Schloss says, such that "producing sequence data is no longer a bottleneck." An expert panel recently recommended that NHGRI "fund larger numbers of smaller centers, and we're using the stimulus money to do some of that. In the early days, genome centers chose one of two [commercial sequencing] platforms, but we're not seeing that now. It's still volatile, but it is a good thing to see diversity and competition."

"We sell data, not instruments," says Complete Genomics's Reid. The company tracks grant proposals, reconnecting with potential clients once projects are funded and sequencing expertise and services are sought. "We anticipated that many of those funded proposals will turn into projects for us to drive our very large sequencing center and to grow our business," he says. Although it is too "early for us to measure in terms of transactions, the numbers of grants we read give us a lot of confidence that we should continue to invest and expand."

The stimulus money will probably trigger a buying spree, as the lag between submission and funding of NIH research proposals has shrunk. This accelerated buying could, however, strain some companies to meet customer demand. "We're going to double the size of our group," says Reid. "Stimulus or no stimulus, it puts our company in the position of satisfying orders, our biggest challenge for 2010 when we release our first product. But you'll hear no complaints from me on this."

Jeffrey L Fox Washington, DC

\title{
ARRA boosts cancer programs but impact on personalized medicine unclear
}

The cancer field is poised to thrive under ARRA, but support for diagnostic firms that could further the goal of personalizing cancer therapeutics has been less forthcoming. According to the Office of the Director, the National Cancer Institute received $\$ 1.26$ billion of the NIH's ARRA monies, including $\$ 731$ million in grants, $\$ 494$ million in R\&D contracts for the academic community, $\$ 6$ million for intramural funding and $\$ 25$ million of support. Eighteen of the 37 challenge grants $\mathrm{NCI}$ sent to $\mathrm{NIH}$ are being funded to the tune of $\$ 17.7$ million; plus NIH is putting up $\$ 38$ million to cover 41 additional high-priority $\mathrm{NCl}$ grants. There's also $\$ 36$ million going to fund 37 early-phase clinical trials of compounds that, according to $\mathrm{NCl}$ director John Niederhuber, "we hope will soon expand our ability to provide targeted, personalized medicine."

Nonetheless, according to some observers, ARRA's impact on personalized medicine and cancer treatment, where the bulk of such research is focused, could be greater.

One reason is the holdup in the anticipated change to the Small Business Innovative Research (SBIR) program that would allow a flow of ARRA funds to venture capital-backed companies (see page 1065). Notes David Parkinson, CEO of Nodality in S. San Francisco, California, "Anticipating that the law would change, we applied for an SBIR grant, negotiated a budget, but then had to withdraw from what would have been an award because of the failure of Congress to reconcile the SBIR law."

Even more importantly, diagnostics companies like Nodality, which is using flow cytometry to measure many signaling pathways concurrently to gain greater insight into why individuals respond or don't respond to particular therapeutic approaches, are not yet on the radar screen of policy makers. "Largely because the diagnostics companies have not been at the table, there's been little discussion of how to help the application of these new technologies to patient characterization," Parkinson says. "Much of the allocation of stimulus money from $\mathrm{NCl}$ was for support of upstream biology, such as genomic sequencing. I thought there would be value to looking strategically at the application of this kind of funding to the downstream interface between all this new biology and information."

That view is echoed by Stephen Friend, the founder of Sage, a not-for-profit initiative located in Seattle that is developing biological networks to model disease across tissues and organs. There's nothing in the NIH system or in pharma, he suggests, that advances the Obama administration's goal of ascertaining who's getting what care and whether that care is working. "I feel there is still a real opportunity for the government to increase transparency in the care of patients. Not just for us or for companies like Nodality. There's a real interest that hasn't been tapped and, more importantly, hasn't been funded."
Mark Ratner 